\title{
Valuation of a-Fe203@C2OH38011 NC Nano- cellulose Surface Coating on Ascorbic Acid Content of Solanum Lycopersicum Under Storage Conditions
}

Geetika Guleria

Eternal University

Dhananjay K. Sharma

Institute of Physics Czech Academy of Sciences: Fyzikalni ustav Akademie ved Ceske republiky

Shweta Thakur

Lingayas University: Lingayas Vidyapeeth

Poonam Kumari

Eternal University

Mamta Shandilya

Shoolini University

Sapna Thakur ( $\nabla$ sapna@eternaluniversity.edu.in )

Eternal University https://orcid.org/0000-0003-1953-2683

\section{Research Article}

Keywords: Fe2O3 NPs, a-Fe2O3@C20H38011 NC, Antimicrobial, XRD, SEM, FTIR, AAS

Posted Date: April 16th, 2021

DOl: https://doi.org/10.21203/rs.3.rs-355073/v1

License: (9) (i) This work is licensed under a Creative Commons Attribution 4.0 International License.

Read Full License 


\section{Abstract}

Competence of synthesized a- $\mathrm{Fe}_{2} \mathrm{O}_{3} @ \mathrm{C}_{20} \mathrm{H}_{38} \mathrm{O}_{11} \mathrm{NC}$ nano-cellulose antimicrobial coating material and its real-time application to extend storage life of Tomato (Solanum lycopersicum) variety Solan Lalima (India) was studied. $\mathrm{Fe}_{2} \mathrm{O}_{3} \mathrm{NPs}$ (nanoparticles) were synthesized using a hydrothermal method, and a$\mathrm{Fe}_{2} \mathrm{O}_{3} @ \mathrm{C}_{20} \mathrm{H}_{38} \mathrm{O}_{11} \mathrm{NC}$ nanocomposite was developed and characterized using XRay Diffractions (XRD) and Scanning Electron Microscopy (SEM) techniques. a- $\mathrm{Fe}_{2} \mathrm{O}_{3} @ \mathrm{C}_{20} \mathrm{H}_{38} \mathrm{O}_{11} \mathrm{NC}$ nanocomposite, and CE (cellulose) were analysed for their antimicrobial activity against Klebsiella pneumoniae and Staphylococcus aureus bacteria. NC exhibit $11 \mathrm{~mm}, 13 \mathrm{~mm}$ zone of inhibition against Klebsiella pneumoniae and Staphylococcus aureus respectively. Tomato fruit samples coated with (5\%) UC1A, UC2A, and (3\%) UC1B, UC2B two different concentrations of a- $\mathrm{Fe}_{2} \mathrm{O}_{3} @ \mathrm{C}_{20} \mathrm{H}_{38} \mathrm{O}_{11} \mathrm{NC}$ nanocomposite and uncoated sample $\mathrm{UC} 1, \mathrm{UC} 2$ stored at room temperature $\left(25 \pm 2{ }^{\circ} \mathrm{C}\right)$ and refrigerator temperature $\left(4^{\circ} \mathrm{C}\right)$ respectively for ascorbic acid (vitamin $\mathrm{C}$ ) analysis on days $0,4,8,12$ and 16 . Our study revealed that a $3 \%$ concentration of a-Fe $\mathrm{F}_{2} \mathrm{O}_{3} @ \mathrm{C}_{20} \mathrm{H}_{38} \mathrm{O}_{11} \mathrm{NC}$ nanocomposite material quite potent in maintaining quality aspects of the tomato fruit by no decline of vitamin $C$ under refrigerator conditions up to $16^{\text {th }}$ day. FTIR analysis of all samples was done to determine the functional groups present in tomato samples after storage. AAS (Atomic Absorption Spectrometer) was used to analyse the content of $\mathrm{Fe}$, and $\mathrm{Zn}$ elements in tomato samples. This work revealed that the $3 \% \mathrm{a}-\mathrm{Fe}_{2} \mathrm{O}_{3} @ \mathrm{C}_{20} \mathrm{H}_{38} \mathrm{O}_{11} \mathrm{NC}$ nano-cellulose antimicrobial nano-coating had maintained the quality of the coated tomato fruits and retards microbial growth during storage time and helpful in increasing the shelf life of tomato under cold storage as well as at room temperature. Coating material had not any significant effect on micronutrients element concentrations in both temperature studies. Synthesised a- $\mathrm{Fe}_{2} \mathrm{O}_{3} @ \mathrm{C}_{20} \mathrm{H}_{38} \mathrm{O}_{11} \mathrm{NC}$ antimicrobial nano-coating material can be used effectively for long storage of tomato fruits and safe for dietary intake of human.

\section{Introduction}

Vegetables/Fruits are essential sources of vitamins and other minerals that play a vital role in the human diet. In recent times, food packaging technology and food quality control have become imperative subjects of research. Retain of nutrition, quality of food or crop products and shelf life enhancement are compensating additional consideration of scientific research using unconventional methods (Galstyan et al. 2018). Bio-nanotechnology blends chemical approaches to biological principles, having expounded applications (Thakur et al. 2018b). Foodborne pathogens have a significant impact on human health as well as country economy (Ezhilan et al. 2018). The edible coating for food by using nanoparticles showing its antimicrobial activity and protect food from deterioration by retaining its quality (de São José et al. 2021). However nanotechnology endow with new way in the antimicrobial evaluation against pathogenic microbes. $\mathrm{Fe}^{2+}$ or $\mathrm{Fe}^{3+}$ nanoparticles loaded chitosan with different concentration were analyzed for antimicrobial activities against Staphylococcus aureus, Escherichia coli and Candida albicans microbes in vitro (Konwar et al. 2016). $\mathrm{Fe}_{3} \mathrm{O}_{4}$ Cysteine HNQ nano complexes exhibit good antimicrobial activity against Staphylococcus aureus and increased wettability on stainless steel 
substrate (contact angle $\sim 20^{\circ}$ ) (Sangeetha and Philip 2013). Cu nanoparticles were reported having potent anti-pathogenicity against E. coli, B. subtilis, S. typhi, K. pneumonia, and S. aureus pathogens (Thakur et al. 2014; Thakur et al. 2018a). Nanoparticles are penetrated inside the bacterial cell, and cause cell lysis by membrane damage (Kumari et al. 2017; Thakur et al. 2020c). Potential antimicrobial and anti-biofilm activity of Fe doped CuO NPs was analyzed against the Staphylococcus aureus, Staphylococcus epidermid is and Candida albicans (Pugazhendhi et al. 2018). Use of $\mathrm{TiO}_{2}-1 \% \mathrm{Fe}-\mathrm{N}$ nanoparticles for innovative self-cleaning and antimicrobial photocatalytic cotton textiles were studied against five tested bacterial strains, i.e., P. aeruginosa, E. coli, S. aureus, B. subtilis and E. faecalis (Stan et al. 2016).

Tomato (Solanum lycopersicum; family Solanaceae) which is a fruit botanically but classified as a vegetable, is a well-known food (Alam and Goyal 2007). It is the most popular and extensively consumed crop after potato in the world(Shinde et al. 2018). It is cultivated in more than 170 countries globally and produces about 182 million tonnes yield (M.T.) (FAOSTAT 2019). It is a mostly consumable vegetable and is rich in significant phytochemicals namely carotene, lutein, lycopene, neurosporene, phytoene, and phytofluene. Tomato-based food and tomato itself reduces the risk of age-related macular degeneration, blinding disorders, cataracts, and prostate cancer (Khachik et al. 2002; Willcox et al. 2003). The genetic modifications in tomatoes are more desirable to provide improved variety for human consumption. Today, countless varieties of tomatoes have been consumed worldwide in their different form of recipes. Tomato is rich in vitamins, minerals, sugars, essential amino acids, iron, dietary fibres and phosphorus (Ayandiji et al. 2011). The tomato crop is widely serving as a source of income in developing countries globally. Thus crop loss during post-harvest can be $42 \%$ more worldly (Arah et al. 2015a). After postharvest, the handling period is crucial in which the nutritional and qualitative status of fresh produced tomato is affected. These affect the aroma, flavour, texture, and vitamin content as well (Maul et al. 2000).

Packaging material for managing post-harvest complexities of vegetables/fruit crops is still rare in the market. Recently some studies are done related to extending the storage life of eatables with the help of nanomaterials. A chitosan (CS) packaging and chitosan containing nano sized titanium dioxide (CT) were studied to maintain quality and extend the storage life of cherry tomatoes at $20^{\circ} \mathrm{C}$ (Kaewklin et al. 2018). ZnO nanoparticles have potent antimicrobial activity due to ROS and the membrane integrity loss against the food pathogens (Heydari-Majd et al. 2019; Thakur et al. 2020a), like Basillus, Salmonella, Klebsiella, Staphylococcus, and Shigella as well as against spores (Thakur et al. 2021; Venkatasubbu et al. 2016). Chitosan-carboxy methyl cellulose-oleic acid nanocomposite with different concentrations (0.5, 1 and $2 \%$ ) of Zinc oxide nano-particles have been studied as a packaging material of sliced wheat bread to enhance the shelf life for 3-35 days as compared to control (Noshirvani et al. 2017). $\mathrm{TiO}_{2}$ or Ag nanoparticles incorporated into polylactic acid (PLA) matrix as a packaging system was studied for Yunnan cottage cheese stored at $5 \pm 1{ }^{\circ} \mathrm{C}$ for 25 days, and the results revealed that studied packaging system was helpful in maintaining the quality of cheese and shelf life extension to 25 days ( $\mathrm{Li}$ et al. 2018). Cellulose is considered an oxygen scavenging polymer to extend the shelf life of fresh foods while maintaining the 
nutritional quality and preventing discoloration (Cichello 2015). Nanofiber membrane of a$\mathrm{Fe}_{2} \mathrm{O}_{3} / \mathrm{C}_{20} \mathrm{H}_{38} \mathrm{O}_{11}$ nanocomposite exhibits the essential role in the food packaging applications (Shandilya et al. 2020). Iron is serving as a micronutrient and all age groups and most of population in developing countries are affected by Fe deficiency(Verna et al. 2021). Diverse study of Fe on tomato were recently done by biofortification of micronutrients (I, Fe, and Zn) in tomato fruit(ŞAHIN 2020) and by nano treatment of $\mathrm{Fe}_{3} \mathrm{O}_{4}$ in tomato seedlings to increase the Fe content in tomato fruits(Giordani et al. 2012). Recently numerous studies have reported the micronutrients element concentrations in fruits and vegetables samples(Bakkali et al. 2009; Demirbas 2010; Techane et al. 2019). In the present study, a$\mathrm{Fe}_{2} \mathrm{O}_{3} @ \mathrm{C}_{20} \mathrm{H}_{38} \mathrm{O}_{11} \mathrm{NC}$ nanocomposite is considered as a promising aspirant or real-time applications of shelf-life enhancement of tomato fruits as per $\mathrm{Fe}_{2} \mathrm{O}_{3}$ nanoparticles antimicrobial activity, cost efficiency, eco-friendly, and multi-functional properties.

\section{Material And Methods}

\subsection{Synthesis of $\mathrm{Fe}_{2} \mathrm{O}_{3}$ nanoparticles}

$\mathrm{Fe}_{2} \mathrm{O}_{3}$ nanoparticles were synthesized by economically efficient, low temperature method. Ferric chloride hexahydrate $\left(\mathrm{FeCl}_{3}-6 \mathrm{H}_{2} \mathrm{O}, 99 \%\right.$, Sigma-Aldrich, USA), and ammonium hydroxide $(\mathrm{NH} 4 \mathrm{OH}, \min 25 \%$, Sigma-Aldrich, USA) were used for the synthesis of a- $\mathrm{Fe}_{2} \mathrm{O}_{3}$ nanoparticles. Took deionized (DI) water 20 $\mathrm{ml}$ as a solvent and add ferric chloride hexahydrate in it to make $0.5 \mathrm{M}$ solution and mix well. Add surfactant drop wise in the mixture and stirred till the reagents were completely dissolved and $\mathrm{pH}$ level of solution was maintained12. The prepared mixture was relocated in Teflon jar of $100 \mathrm{ml}$ capacity lined with stainless steel autoclaves at $150{ }^{\circ} \mathrm{C}$ for $48 \mathrm{~h}$. After the complete reaction the mixture was transferred in $10 \mathrm{ml}$ capacity tubes, centrifuged and rinsed with ethanol and DI water four times repeatedly. The synthesized $\mathrm{Fe}_{2} \mathrm{O}_{3}$ nanoparticles were dried at $60^{\circ} \mathrm{C}$ for $24 \mathrm{~h}$.

\subsection{Synthesis of $\mathrm{a}-\mathrm{Fe}_{2} \mathrm{O}_{3} @ \mathrm{C}_{20} \mathrm{H}_{38} \mathrm{O}_{11} \mathrm{NC}$ nanocomposite}

For the synthesis of a- $\mathrm{Fe}_{2} \mathrm{O}_{3} @ \mathrm{C}_{20} \mathrm{H}_{38} \mathrm{O}_{11} \mathrm{NC}$ nanocomposite $\mathrm{C}_{20} \mathrm{H}_{38} \mathrm{O}_{11}$ (Ethyl cellulose; Sigma Aldrich, USA) powder was dissolved with ethanol (Loba Chemie) at $40{ }^{\circ} \mathrm{C}$ to make $3 \%$ solution. $\mathrm{Fe}_{2} \mathrm{O}_{3}$ nanoparticles were mixed with ethyl cellulose in $100 \mathrm{ml}$ solvent media and make two different concentrations of $0.5 \%$, and $0.3 \%$ using a sonicator. The prepared different concentrations of a$\mathrm{Fe}_{2} \mathrm{O}_{3} @ \mathrm{C}_{20} \mathrm{H}_{38} \mathrm{O}_{11} \mathrm{NC}$ nanocomposite applied over the surface of Tomato (Solanum lycopersicum) varieties Solan Lalima (Himachal Pradesh, India) and kept under two different temperature conditions at room temperature $\left(25 \pm 2^{\circ} \mathrm{C}\right)$ and refrigerator temperature $\left(4^{\circ} \mathrm{C}\right)$ respectively for ascorbic acid analysis.

\subsection{Antibacterial screening}

The antibacterial activities of synthesized $\mathrm{a}-\mathrm{Fe}_{2} \mathrm{O}_{3} @ \mathrm{C}_{20} \mathrm{H}_{38} \mathrm{O}_{11} \mathrm{NC}$ nano-composite antimicrobial nanocoating material and cellulose were studied by agar well diffusion method against Gram-negative bacteria (Klebsiella pneumoniae) and Gram-positive bacteria (Staphylococcus aureus). The bacterial 
cultures were obtained from Department of Biotechnology, Akal College of Agriculture, Eternal University, Sirmaur, Himachal Pradesh, India. Bacterial strains grown on nutrient agar at $37^{\circ} \mathrm{C}$ for $20 \mathrm{hr}$ were suspended in a saline solution and turbidity adjusted to $0.5 \mathrm{MacFarl}$ and $\left(10^{8} \mathrm{CFU} / \mathrm{ml}\right.$ ) (Thakur et al. 2020a; Thakur et al. 2014; Thakur et al. 2020b).

\subsection{Ascorbic acid analysis}

Fresh and mature (red) tomato (Solanum lycopersicum) fruit of uniform size and mass were collected from Baba Mahender Singh farm, DKSG Akal college of agriculture, Eternal University, Baru Sahib, (H.P.). The weight of individual tomato fruit varied from $100 \mathrm{~g}$ to $105 \mathrm{~g}$. Tomato was coated with the synthesized a- $\mathrm{Fe}_{2} \mathrm{O}_{3} @ \mathrm{C}_{20} \mathrm{H}_{38} \mathrm{O}_{11} \mathrm{NC}$ nanocomposite material using the dipping method (3 min) in two different concentrations $(0.5, \& 0.3)$. The Ascorbic acid content in uncoated and coated tomato fruit samples were evaluated at regular storage intervals of approximately two weeks; stored at room temperature $\left(25 \pm 2{ }^{\circ} \mathrm{C}\right)$ and refrigerator temperature $\left(4^{\circ} \mathrm{C}\right)$ conditions. Random sample of 3 fruit per concentration were used to analyse vitamin $\mathrm{C}$ content in tomato.

Vitamin $\mathrm{C}$ content in stored tomato samples was determined by the titration method. The ascorbic acid was extracted from samples with metaphosphoric acid. Titration of the filtered extracts was done using 2,6-dichlorophenol indophenol, the colour changed from blue to light pink. Vitamin $\mathrm{C}$ was analysed using tomato tissue from the uncoated and coated site. All the measurements were performed in three replicates (Giovanelli et al. 1999; Sablani et al. 2006).

\subsection{Instruments used for characterization}

$\mathrm{a}-\mathrm{Fe}_{2} \mathrm{O}_{3}$ nanoparticles were studied for their structural and phase identification using X-ray diffraction(XRD) analyser (PW3040 Philips X-ray diffractometer having CuKa radiation $(k=0.15406 \mathrm{~nm})$. The surface morphology of the $\mathrm{a}-\mathrm{Fe}_{2} \mathrm{O}_{3}$ nanoparticles and synthesized a- $\mathrm{Fe}_{2} \mathrm{O}_{3} @ \mathrm{C}_{20} \mathrm{H}_{38} \mathrm{O}_{11} \mathrm{NC}$ nanocomposite was studied with the help of Field Emission Scanning Electron Microscopy (FE-SEM, JSM-7001F). FTIR spectroscopy was used to determine the functional groups present in control and coated tomato samples. Atomic Absorption Spectrometer (AA240FS, Agilent Technology, CA, USA) was used to determining the concentration of a Fe elemental in tomato samples considered for the storage study.

\subsection{AAS (Atomic Absorption Spectrometer) analysis}

Total Fe along with Zn content in the pulp of storage tomato samples UC1, UC1A, UC1B, UC2, UC2A and UC2B were analysed through digestion method. Tomato samples were washed with DI water thoroughly for 5 minutes. After peeling off the outer covering chopped tomato samples were dried in hot air oven at $60^{\circ} \mathrm{C}$ for 3 days. The dried tomato $(0.5 \mathrm{~g})$ were digested in microwave digester (Anton Paar, $\mathrm{GmbH}$, Austria) in two portion of concentrated Nitric Acid (Merck) and one portions of $30 \%(\mathrm{~m} / \mathrm{m}) \mathrm{H}_{2} \mathrm{O}_{2}$ to get a clear solution in triplicate(Bressy et al. 2013; Techane et al. 2019). Digested tomato samples were then transferred to falcon tubes, making final volume $25 \mathrm{ml}$ by adding $\mathrm{DI}$ water for further Atomic Absorption 
Spectrometer (AA240FS, Agilent technology, CA, USA) analysis against standards of Fe, and Zn (Merck, Darmstadt, Germany).

\section{Results And Discussion}

\subsection{Structural Study}

\subsubsection{XRD (X-Ray Diffraction) Analysis}

The XRD pattern of $\mathrm{a}-\mathrm{Fe}_{2} \mathrm{O}_{3}$ synthesized with the help of the hydrothermal method was analysed Fig.1. The XRD pattern was in good agreement with that of the hematite phase of iron oxide (JCPDS Card no. \#33-0664) with no additional or impurity peaks. The diffraction peaks can be indexed to the rhombohedral (hexagonal) structures of hematite with the lattice parameters $a=b=0.5034$; and $c=13.768$ Á. The sharpen peaks with high FWHM values can be attributed to crystalline structures corresponding to pure a-Fe $\mathrm{O}_{2} \mathrm{O}_{3}$ nanoparticles. The calculated crystallite size was found to be $\sim 70.44 \mathrm{~nm}$ by using DebyeScherrer formula (Patterson 1939).

$$
\mathrm{D}=\frac{k \cdot \lambda}{\beta \cdot \cos \theta} \ldots \ldots \ldots
$$

Where $D$ is the average crystallite size, $k$ is the Scherer's constant, $\lambda$ is the wavelength of radiation for $\mathrm{Cu}$ $\mathrm{Ka}, \theta$ is diffracted angle, and $\beta$ is FWHM of diffracted peaks. The physical parameters such as lattice strain and crystallite size are evaluated with X-ray peak broadening analysis. It can be clearly seen from equation (1) that the crystallite size (D) of nanoparticles is inversely proportional to the peak broadening $(\beta)$ of the diffracted peaks. The Scherrer plot of $\mathrm{Fe}_{2} \mathrm{O}_{3}$ nanoparticles are shown in Fig.2 (a) with a linear relationship between $y$ - $\operatorname{co-ordinate}$ as $\cos \theta$ and $x$-co-ordinate $a s 1 / \beta$. The crystallite size and lattice strain in the sample was also calculated by using the Williamson-Hall(W-H) method (llyas et al., 2019). Equation (2) is a representation of the W-H method, which gives a relationship between crystallite size (D) and lattice strain ( $(\mathbb{)})$

$$
\beta \cos \Theta=(\mathrm{K} . \lambda) / \mathrm{D}+4 \varepsilon \sin \Theta
$$

The W-H plot of the nanoparticles is shown in Fig.2 (b) with a linear relationship between y-co-ordinate as $\beta \cos \theta$ and $x$-co-ordinate as $4 \sin \theta$. The value of lattice strain was extracted from the intercept of the linear fit and found to be $0.77 \times 10-3$ whereas the crystallite size was estimated from the slope of the linear fit made to the plot and found to be $\sim 74.5 \mathrm{~nm}$.

\subsubsection{Scanning Electron Diffraction (SEM) Analysis}

The surface morphology and particle size of the $\mathrm{Fe}_{2} \mathrm{O}_{3}$ nanoparticles and $\mathrm{a}-\mathrm{Fe}_{2} \mathrm{O}_{3} @ \mathrm{C}_{20} \mathrm{H}_{38} \mathrm{O}_{11} \mathrm{NC}$ nanocomposite was determined with the help of scanning electron microscopy (SEM) analysis. Fig.3(a, b) represents the SEM images of the as-synthesized $\mathrm{Fe}_{2} \mathrm{O}_{3}$ nanoparticles and a- $\mathrm{Fe}_{2} \mathrm{O}_{3} @ \mathrm{C}_{20} \mathrm{H}_{38} \mathrm{O}_{11} \mathrm{NC}$ 
nanocomposite, respectively. It was observed that the pristine $\mathrm{Fe}_{2} \mathrm{O}_{3}$ nanoparticles were highly dense and uniform with high crystallinity and spherical shape. It was clear from Fig.3(a) that the $\mathrm{Fe}_{2} \mathrm{O}_{3}$ nanoparticles formed were softly agglomerated. However, when $\mathrm{Fe}_{2} \mathrm{O}_{3}$ nanoparticles were mixed with cellulose, the morphology of the particles changed its shape, and the agglomeration was reduced drastically as shown in Fig.3(b). The average particle size for $\mathrm{Fe}_{2} \mathrm{O}_{3}$ nanoparticles is about $\sim 180 \pm 30 \mathrm{~nm}$ whereas the particle size was found to decrease in the case of $\mathrm{a}-\mathrm{Fe}_{2} \mathrm{O}_{3} @ \mathrm{C}_{20} \mathrm{H}_{38} \mathrm{O}_{11} \mathrm{NC}$ nanocomposite to about $\sim 60 \pm 15 \mathrm{~nm}$. This drastic diminution in particle size because cellulose as a solvent endorses selfassembly process. This non-classical process of grain modification trims down the agglomeration of $\mathrm{Fe}_{2} \mathrm{O}_{3}$ nanoparticles due to high surface energy. Modified nanoparticles are exceedingly recitalist towards the surface activity because of increased surface volume ratio. The EDX-pattern of a- $\mathrm{Fe}_{2} \mathrm{O}_{3} @ \mathrm{C}_{20} \mathrm{H}_{38} \mathrm{O}_{11}$ $\mathrm{NC}$ nanocomposite is in good agreement of the stoichiometric presence of the expected elements in the sample Fig.3(c).

\subsection{Antibacterial screening}

$\mathrm{a}-\mathrm{Fe}_{2} \mathrm{O}_{3} @ \mathrm{C}_{20} \mathrm{H}_{38} \mathrm{O}_{11} \mathrm{NC}$ nanocomposite and Cellulose were subjected to antibacterial activity against Klebsiella pneumoniae and Staphylococcus aureus, both gram-negative and gram-positive bacteria. In this study, the zone of inhibition analyzed for both organisms a- $\mathrm{Fe}_{2} \mathrm{O}_{3} @ \mathrm{C}_{20} \mathrm{H}_{38} \mathrm{O}_{11} \mathrm{NC}$ nanocomposite synthesized using the hydrothermal method exhibited significant activity against Klebsiella pneumoniae $(11 \mathrm{~mm})$ Staphylococcus aureus $(13 \mathrm{~mm})$, whereas cellulose paste poses no antimicrobial activity against both the bacteria. Synthesized a- $\mathrm{Fe}_{2} \mathrm{O}_{3} @ \mathrm{C}_{20} \mathrm{H}_{38} \mathrm{O}_{11} \mathrm{NC}$ nanocomposite exhibited promising antimicrobial activity due to proper dispersal of Iron nanoparticles in cellulose, and its synergistic effect and results were tabulated along with figures Fig. 4. (Table 1). ROS factors should be responsible for the potent antibacterial effect of synthesized nanomaterials (Abdal Dayem et al. 2017; Das et al. 2017). ROS amount of a- $\mathrm{Fe}_{2} \mathrm{O}_{3} @ \mathrm{C}_{20} \mathrm{H}_{38} \mathrm{O}_{11} \mathrm{NC}$ nanocomposite associates with the size, shape, and chemistry of synthesized nanocomposite materials. ROS response of metal nanoparticles is a key factor in modulating cellular signalling involved in bacterial cell death, and proliferation.

\subsection{Ascorbic acid analysis during storage in tomato (Solanum lycopersicum) fruit}

The ascorbic acid content in tomato (Solanum lycopersicum) fruit was analyzed under the effect of two different concentrations of a- $\mathrm{Fe}_{2} \mathrm{O}_{3} @ \mathrm{C}_{20} \mathrm{H}_{38} \mathrm{O}_{11} \mathrm{NC}$ nanocomposite $(5 \%, \& 3 \%)$. All samples were kept at two different storage temperatures: room temperature $\left(25 \pm 2{ }^{\circ} \mathrm{C}\right)$ and refrigerator temperature $\left(4{ }^{\circ} \mathrm{C}\right)$ for day 0 , day 4 , day 8 , day 12 , and day 16 . The content of ascorbic acid (vitamin $\mathrm{C}$ ) in tomatoes fruit samples used in this study was about $28 \mathrm{mg} / 100 \mathrm{~g}$ (Stevens 1974). Recent studies reported that ascorbic acid content in whole mature-red fresh tomatoes was 13 and $26 \%$ higher than in mature pink and mature light pink tomatoes, respectively (Chomchalow et al. 2002). Storage study revealed that Fig. 5 with increasing storage time decline in vitamin $\mathrm{C}$ content in tomato fruit was higher at room temperatures $\left(25 \pm 2{ }^{\circ} \mathrm{C}\right)$ in uncoated tomato sample UC1. Almost $50 \%$ vitamin $\mathrm{C}$ content declined, and $8 \%$ loss of moisture was observed on $8^{\text {th }}$ day of storage at room temperature in sample UC 1 ; after $10^{\text {th }}$ day of 
storage sample UC1 was spoiled and vitamin $\mathrm{C}$ analysis was not performed after this. In coated tomato samples UC1A (5\% concentration of $\mathrm{a}-\mathrm{Fe}_{2} \mathrm{O}_{3} @ \mathrm{C}_{20} \mathrm{H}_{38} \mathrm{O}_{11} \mathrm{NC}$ nanocomposite) 47\% decline in vitamin $\mathrm{C}$ content on $12^{\text {th }}$ day of storage at room temperature after that UC1A sample was spoiled. In coated tomato samples UC1B ( $3 \%$ concentration of a- $\mathrm{Fe}_{2} \mathrm{O}_{3} @ \mathrm{C}_{20} \mathrm{H}_{38} \mathrm{O}_{11} \mathrm{NC}$ nanocomposite) vitamin C loss in tomato was lower than UC1A and UC1; decline in vitamin C content was $36 \%$ at $16^{\text {th }}$ day of storage at room temperature.

Whereas vitamin $\mathrm{C}$ content in tomato fruit stored at refrigeration temperature $\left(4^{\circ} \mathrm{C}\right)$ was lower than tomato fruit stored at room temperatures $\left(25 \pm 2{ }^{\circ} \mathrm{C}\right)$ Fig. 6 . In uncoated tomato sample UC2 (held at refrigeration temperature $4{ }^{\circ} \mathrm{C}$ ) the vitamin $\mathrm{C}$ content declined by $43 \%$ and $7 \%$ loss of moisture at $16^{\text {th }}$ day of storage. In coated tomato samples UC2A ( $5 \%$ concentration of a-Fe $\mathrm{O}_{2} @ \mathrm{O}_{3} \mathrm{C}_{20} \mathrm{H}_{38} \mathrm{O}_{11} \mathrm{NC}$ nanocomposite) $29 \%$ decline in vitamin $\mathrm{C}$ content at $16^{\text {th }}$ day of storage and in coated tomato samples UC2B (3\% concentration of $\mathrm{a}-\mathrm{Fe}_{2} \mathrm{O}_{3} @ \mathrm{C}_{20} \mathrm{H}_{38} \mathrm{O}_{11} \mathrm{NC}$ nanocomposite) vitamin $\mathrm{C}$ loss in tomato was lower as compared to UC2A, UC1A, UC2 and UC1; decline in vitamin C content was just $11 \%$ at $16^{\text {th }}$ day of storage at refrigeration temperature. The study revealed that $3 \%$ coating of synthesized a$\mathrm{Fe}_{2} \mathrm{O}_{3} @ \mathrm{C}_{20} \mathrm{H}_{38} \mathrm{O}_{11} \mathrm{NC}$ nanocomposite was able to keep tomato fruits fresh after 16 days of storage under refrigeration temperature. Tomatoes are sensitive to chilling conditions and urged storage temperature for tomato fruits varies with the ripening and maturity stage. Tomato fruits and other vegetables/fruits show a continuing loss in ascorbic acid content with long storage duration and increased temperature (Heinze 1974; Watada and Tran 1987). Bruising is a widespread problem occur at several stages of post-harvest handling and marketing of vegetables/fruits (Hussein et al. 2019; Opara and Pathare 2014; Sablani et al. 2006). Vitamin C degradation or chemical composition alteration may be due to microbial contamination or damage to the tissue.

Present storage study revealed that on uncoated tomato fruits, duration and temperatures variations influence on vitamin $\mathrm{C}$ content was significant $(\mathrm{p}>0.05)$ compared to the synthesized $\mathrm{a}-\mathrm{Fe}_{2} \mathrm{O}_{3} @ \mathrm{C}_{20} \mathrm{H}_{38} \mathrm{O}_{11}$ $\mathrm{NC}$ nanocomposite coated tomato fruits samples. Recent researches shown that vitamin $\mathrm{C}$ content in damaged tomato tissue was 15 to $16 \%$ lower than unbruised or undamaged tissue (Hussein et al. 2018; Ismail et al. 1993). These results indicated that a- $\mathrm{Fe}_{2} \mathrm{O}_{3} @ \mathrm{C}_{20} \mathrm{H}_{38} \mathrm{O}_{11} \mathrm{NC}$ nanocomposite coating significantly affected the chemical composition of surface tissues of tomato fruit and $3 \% \mathrm{a}-$ $\mathrm{Fe}_{2} \mathrm{O}_{3} @ \mathrm{C}_{20} \mathrm{H}_{38} \mathrm{O}_{11} \mathrm{NC}$ nanocomposite was more effective in maintaining the quality of tomato after 16 days of storage under refrigeration temperature as well as at room temperature. Therefore, it is possible to increase the storage life of vegetables/fruits under natural conditions without adding and pesticide or hazard chemicals.

\subsection{Fourier Transform Infrared radiation (FTIR) spectroscopy}

FTIR analysis was done to determine the functional groups present in a- $\mathrm{Fe}_{2} \mathrm{O}_{3} @ \mathrm{C}_{20} \mathrm{H}_{38} \mathrm{O}_{11} \mathrm{NC}$ nanocomposite. Sharp peaks observed at $2973 \mathrm{~cm}^{-1}$ and $2876 \mathrm{~cm}^{-1}$ shown the presence of $-\mathrm{CHO}$ vibration or alkane stretching and peak observed at $1375 \mathrm{~cm}^{-1}$ were due to $-\mathrm{CH}_{2}$ bending (Huang et al. 
2012). A small peak at $3461 \mathrm{~cm}^{-1}$ exposed the presence of $-\mathrm{OH}$ group of alcohol (Mohammad et al. 2017). The Fe- 0 stretching was present on $540 \mathrm{~cm}^{-1}$ and a sharp peak was observed at $1050 \mathrm{~cm}^{-1}$ due to C-O bonds of secondary metabolites present in biodegradable cellulose polymer (Shandilya et al. 2020)

Fig. 7(a). Same well-defined sharp peaks of C-O stretching were observed at $1022 \mathrm{~cm}^{-1}, 1029 \mathrm{~cm}^{-1}$ in the FTIR spectrum of stored tomato samples (tomato dry fruit pulp) UC1, UC1A and UC1B samples kept at room temperature $\left(25^{\circ} \mathrm{C}\right.$ ) Fig. $7($ b) and (tomato dry fruit pulp) UC2, UC2A and UC2B samples kept at refrigerator conditions $\left(4^{\circ} \mathrm{C}\right)$ Fig. 7 (c) respectively.

The prominent broad peak of $\mathrm{C}-\mathrm{O}$ was associated with the cellulose and pectin compounds in tomato fruits (Skolik et al. 2019a; Skolik et al. 2019b). FTIR study revealed out the primary and secondary metabolites functional groups present in tomato fruit after kept them under storage study. Sharp peaks were observed at $1223 \mathrm{~cm}^{-1}, 1231 \mathrm{~cm}^{-1}$ is due to $\mathrm{C}-\mathrm{OH}$ bending vibrations(Doodran) and associated with monoterpenes (Ord et al. 2016), secondary metabolites comprising potentially volatile organic chemicals (VOCs) during ripening (Buttery et al. 1988; Skolik et al. 2019a). The peak at $1402 \mathrm{~cm}^{-1}$ vibration band related to the other alkane, polysaccharides and $1611 \mathrm{~cm}^{-1}, 1604 \mathrm{~cm}^{-1}$ may simply be a broad, vibration band related to ketones, monoterpenes representative of VOCs present at the ripen phase of tomato fruits(Rodríguez et al. 2013). The advent of strong and broad intensity band at $649 \mathrm{~cm}^{-1}, 664 \mathrm{~cm}^{-1}$ was confirmed the presence of $\mathrm{Fe}-\mathrm{O}$ starching in all tomato samples including controls(Święch et al. 2018). Merged peaks were observed at $2163 \mathrm{~cm}^{-1}, 2178 \mathrm{~cm}^{-1}$ of C-C alkynes and $2618 \mathrm{~cm}^{-1}, 2174 \mathrm{~cm}^{-1}$ ofC-H aldehydes secondary metabolites of tomato (Doodran). Vibrant merged peaks were analysed at $3372 \mathrm{~cm}^{-}$ $1,3379 \mathrm{~cm}^{-1}, 3297 \mathrm{~cm}^{-1}, 3335 \mathrm{~cm}^{-1}, 3215 \mathrm{~cm}^{-1}$, and $3230 \mathrm{~cm}^{-1}$ represent the $\mathrm{O}-\mathrm{H}$ stretching of carboxylic acid. FTIR spectra revealed that ripened tomatoes kept under $\mathrm{a}-\mathrm{Fe}_{2} \mathrm{O}_{3} @ \mathrm{C}_{20} \mathrm{H}_{38} \mathrm{O}_{11} \mathrm{NC}$ nanocomposite storage study have increased amount of glycerol-lipids, primary phenolic compounds, cellulose, pectin and other carbohydrates moieties of VOCs.

\subsection{Fe and Zn micronutrients contents}

Concentrations of Fe and Zn micronutrients analysed in UC1, UC1A and UC1B samples $\left(25^{\circ} \mathrm{C}\right)$ and UC2, UC2A and UC2B samples $\left(4^{\circ} \mathrm{C}\right)$ Fig. $8(\mathrm{a}, \mathrm{b})$ (Table 2$)$ taken as a mean of three measurements. The highest Fe concentrations were observed in controls of tomatoesUC1 sample $21.8 \mathrm{mg} / \mathrm{kg}$ on $8^{\text {th }}$ day (after that sample spoiled) and UC2 sample $20.9 \mathrm{mg} / \mathrm{kg}$ on $16^{\text {th }}$ day respectively. Study revealed that there were no penetrations of Fe nanoparticles through a- $\mathrm{Fe}_{2} \mathrm{O}_{3} @ \mathrm{C}_{20} \mathrm{H}_{38} \mathrm{O}_{11} \mathrm{NC}$ nanocomposite coating in tomato fruits during 16 days of storage. Fe content was decreased during storage; on $10^{\text {th }}$ day when UC1A sample was observed Fe content was $18.4 \mathrm{mg} / \mathrm{kg}$ and on $16^{\text {th }}$ day in UC1B sample Fe content was $16.52 \mathrm{mg} / \mathrm{kg}$. Tomato samples kept in $4^{\circ} \mathrm{C}$ for storage study have stable Fe concentration i.e. in UC2A sample $20.5 \mathrm{mg} / \mathrm{kg}$ and in UC2B sample $20.7 \mathrm{mg} / \mathrm{kg}$. On the other hands, there were fluctuations in Zn concentration. Lowest $\mathrm{Zn}$ concentrations were observed in controls of tomatoes $20.4 \mathrm{mg} / \mathrm{kg}$ and 21.4 $\mathrm{mg} / \mathrm{kg} \mathrm{UC1}$ and UC2 samples respectively. Zn content was increased during storage; on $10^{\text {th }}$ day in UC1A sample $24.7 \mathrm{mg} / \mathrm{kg}$ and on $16^{\text {th }}$ day in UC1B sample Zn content was $22.4 \mathrm{mg} / \mathrm{kg}$. Tomato samples kept 
in $4^{\circ} \mathrm{C}$ for storage study have also increase in Zn concentration i.e. in UC2A sample22.4 mg/ $\mathrm{kg}$ and in UC2B sample $22.5 \mathrm{mg} / \mathrm{kg}$ on $16^{\text {th }}$ day of storage. 20 cultivars of $S$. lycopersicum L. and 10 wild relatives were analysed for mineral ( $\mathrm{Na}, \mathrm{K}, \mathrm{Ca}, \mathrm{Mg}$ )and trace elements ( $\mathrm{Cu}, \mathrm{Fe}, \mathrm{Zn}, \mathrm{Mn}$ ) content (Fernández-Ruiz et al. 2011). Heavy metal contents, oil and micronutrients were analysed in tomato seeds and (Lycopersicon esculentum) fruits from Turkish resources; 1.98 -2.41 mg/kg Fe content and 64.8-78.4 mg/kg Zn content (dry weight basis) was found in different tomato samples (Demirbas 2010).

\section{Conclusion}

Tomato fruits are the richest source of ascorbic acid and antioxidants; they play an essential role in dayto-day life of the human diet at each level. Eating tomato as a good source of vitamin $\mathrm{C}$ is widely suggested in the research literature as a protective supplement against chronic diseases (Jacob et al. 2008; Joshipura et al. 2001; Ntagkas et al. 2019; Willcox et al. 2003). Management of ascorbic acid in tomato fruit during post-harvest handling and storage is essential. In our present study, the amount of vitamin $\mathrm{C}$ in uncoated tomato fruit decreased with increasing storage duration at room temperatures, and tomato get spoiled after 9 days of storage. The as-prepared synthesized $a-\mathrm{Fe}_{2} \mathrm{O}_{3} @ \mathrm{C}_{20} \mathrm{H}_{38} \mathrm{O}_{11} \mathrm{NC}$ nanocomposite revealed good antimicrobial activities against gram -ve bacteria Klebsiella pneumoniae i.e. $11 \mathrm{~mm}$, and against gram +ve bacteria Staphylococcus aureus i.e. $13 \mathrm{~mm}$. Post-harvest storage study of ascorbic acid content in $\mathrm{a}-\mathrm{Fe}_{2} \mathrm{O}_{3} @ \mathrm{C}_{20} \mathrm{H}_{38} \mathrm{O}_{11} \mathrm{NC}$ nanocomposite coated tomato fruit samples was observed that the tomato coated with $3 \% \mathrm{NC}$ concentration show extended shelf life at room temperature with $36 \%$ loss in vitamin $\mathrm{C}$ and able to maintain the quality of tomato at refrigeration temperature with only $11 \%$ loss of vitamin $\mathrm{C}$ as compared to other coated and uncoated tomatoes. Post-harvest losses, in on-farm/off-farm are gradually crumbling the tomato industry. Using low-cost, eco-friendly, innovative technology intervention can help in the reduction of post-harvest losses and tomato production will become more profitable for farmers (Arah et al. 2015b; Ayomide et al. 2019). Quantity and quality losses were reported in conventional methods used in tomatoes storage. FTIR analyses shown the increased amount of potentially volatile organic chemicals (VOCs) in ripped tomatoes kept under a$\mathrm{Fe}_{2} \mathrm{O}_{3} @ \mathrm{C}_{20} \mathrm{H}_{38} \mathrm{O}_{11} \mathrm{NC}$ nanocomposite coating in both temperatures. AAS analysis revealed that $\mathrm{Fe}$ content was decreased with long storage time under room temperature studies and $\mathrm{Zn}$ content increased at room temperature; whereas both $\mathrm{Fe}$ and $\mathrm{Zn}$ content remains stable at refrigerator conditions in tomato samples.

Hence, development of an antibacterial a- $\mathrm{Fe}_{2} \mathrm{O}_{3} @ \mathrm{C}_{20} \mathrm{H}_{38} \mathrm{O}_{11} \mathrm{NC}$ nanocomposite controlled post-harvest storage system for tomato-like fruits and vegetables to diminish the rate of vitamin c deterioration and increasing shelf life with good quality and quantity becomes inevitable. Synthesised a- $\mathrm{Fe}_{2} \mathrm{O}_{3} @ \mathrm{C}_{20} \mathrm{H}_{38} \mathrm{O}_{11}$ $\mathrm{NC}$ antimicrobial nano-coating material can be effectively for long storage of tomato fruits and safe for dietary intake of human; FTIR and AAS analysis reflected that coating material had neither significant effect on storage tomato fruit samples. There was no change in Fe content under coating of synthesised $\mathrm{a}-\mathrm{Fe}_{2} \mathrm{O}_{3} @ \mathrm{C}_{20} \mathrm{H}_{38} \mathrm{O}_{11} \mathrm{NC}$ material even after 16 days of storage. Thus, a- $\mathrm{Fe}_{2} \mathrm{O}_{3} @ \mathrm{C}_{20} \mathrm{H}_{38} \mathrm{O}_{11} \mathrm{NC}$ coating 
nanomaterials can be used as a prospective biodegradable packaging film for dynamic food packaging applications.

\section{Declarations}

\section{Acknowledgement}

The authors wish to acknowledge financial support provided by the Department of Science and Technology (DST), Govt. of India, for financial support under the Research Project SR/WOS-A/LS$296 / 2017$.

Funding Authors are grateful to the Department of Science and Technology (DST), Govt. of India, for financial support under the Research Project SR/WOS-A/LS-296/2017.

Availability of data and materials Not applicable.

Code availability Not applicable.

\section{Compliance with ethical standards}

Conflict of interest The authors confirm that there are no conflicts of interest.

\section{Author contributions statement}

Geetika Guleria, Dr. Shweta Thakur and Dr. Poonam Kumari were responsible for performing the experiments and analyzing the data obtained. Dr. D. K. Sharma provided support in the resources and validation. Dr. Mamta Shandilya was done validation, writing - review \& editing of manuscript. Dr. Sapna Thakur devised the main conceptual ideas, designing-supervising the experiments, manuscript writing, conceptualization, and supervision. All authors contributed equally to prepare and review the manuscript.

\section{References}

1. Abdal Dayem A et al. (2017) The role of reactive oxygen species (ROS) in the biological activities of metallic nanoparticles International journal of molecular sciences 18:120

2. Alam T, Goyal G (2007) Packaging and storage of tomato puree and paste

3. Arah IK, Amaglo H, Kumah EK, Ofori H (2015a) Preharvest and postharvest factors affecting the quality and shelf life of harvested tomatoes: a mini review International Journal of Agronomy 2015

4. Arah IK, Kumah E, Anku E, Amaglo H (2015b) An overview of post-harvest losses in tomato production in Africa: causes and possible prevention strategies Journal of Biology, Agriculture and Healthcare 5:78-88

5. Ayandiji A, Adeniyi O, Omidiji D (2011) Determinant post harvest losses among tomato farmers in Imeko-Afon local government area of Ogun State, Nigeria Global Journal of Science Frontier 
Research 11:23-27

6. Ayomide O, Ajayi O, Ajayi A Advances in the development of a tomato postharvest storage system: towards eradicating postharvest losses. In: Journal of Physics: Conference Series, 2019. vol 2. IOP Publishing, p 022064

7. Bakkali K, Martos NR, Souhail B, Ballesteros E (2009) Characterization of trace metals in vegetables by graphite furnace atomic absorption spectrometry after closed vessel microwave digestion Food Chemistry 116:590-594

8. Bressy FC, Brito GB, Barbosa IS, Teixeira LS, Korn MGA (2013) Determination of trace element concentrations in tomato samples at different stages of maturation by ICP OES and ICP-MS following microwave-assisted digestion Microchemical Journal 109:145-149

9. Buttery RG, Teranishi R, Ling LC, Flath RA, Stern DJ (1988) Quantitative studies on origins of fresh tomato aroma volatiles Journal of Agricultural and Food Chemistry 36:1247-1250

10. Chomchalow S, El Assi N, Sargent S, Brecht J (2002) Fruit maturity and timing of ethylene treatment affect storage performance of green tomatoes at chilling and nonchilling temperatures HortTechnology 12:104-114

11. Cichello SA (2015) Oxygen absorbers in food preservation: a review Journal of food science and technology 52:1889-1895

12. Das B et al. (2017) Green synthesized silver nanoparticles destroy multidrug resistant bacteria via reactive oxygen species mediated membrane damage Arabian Journal of Chemistry 10:862-876

13. de São José JFB, Ramos AM, Vanetti MCD, de Andrade NJ (2021) Inactivation of Salmonella Enteritidis on cherry tomatoes by ultrasound, lactic acid, detergent, and silver nanoparticles Canadian Journal of Microbiology 67:1-12

14. Demirbas A (2010) Oil, micronutrient and heavy metal contents of tomatoes Food Chemistry 118:504-507

15. Doodran RJ Removal of heavy metals from industrial effluents with the help of biological extracts of tomato pulp

16. Ezhilan M, Nesakumar N, Babu KJ, Srinandan C, Rayappan JBB (2018) An electronic nose for Royal Delicious Apple Quality Assessment-a tri-layer approach Food Research International 109:44-51

17. Fernández-Ruiz V, Olives Al, Cámara M, de Cortes Sánchez-Mata M, Torija ME (2011) Mineral and trace elements content in 30 accessions of tomato fruits (Solanum lycopersicum L.,) and wild relatives (Solanum pimpinellifolium L., Solanum cheesmaniae L. Riley, and Solanum habrochaites S. Knapp \& DM Spooner) Biological trace element research 141:329-339

18. Galstyan V, Bhandari M, Sberveglieri V, Sberveglieri G, Comini E (2018) Metal oxide nanostructures in food applications: Quality control and packaging Chemosensors 6:16

19. Giordani T et al. (2012) Response of tomato plants exposed to treatment with nanoparticles EQAInternational Journal of Environmental Quality 8:27-38 
20. Giovanelli G, Lavelli V, Peri C, Nobili S (1999) Variation in antioxidant components of tomato during vine and post-harvest ripening Journal of the Science of Food and Agriculture 79:1583-1588

21. Heinze $P$ (1974) influence of storage, transportation and marketing conditions on composition and nutritional values of fruits and vegetables Nutritional Qualities of Fresh Fruits and Vegetables $p \mathrm{~L}$ White, \& N Selvey, eds

22. Heydari-Majd M, Ghanbarzadeh B, Shahidi-Noghabi M, Najafı MA, Hosseini M (2019) A new active nanocomposite film based on PLA/ZnO nanoparticle/essential oils for the preservation of refrigerated Otolithes ruber fillets Food Packaging and Shelf Life 19:94-103

23. Huang L-Y, Yu D-G, Branford-White C, Zhu L-M (2012) Sustained release of ethyl cellulose microparticulate drug delivery systems prepared using electrospraying Journal of Materials Science 47:1372-1377

24. Hussein Z, Fawole OA, Opara UL (2018) Preharvest factors influencing bruise damage of fresh fruits-a review Scientia horticulturae 229:45-58

25. Hussein Z, Fawole OA, Opara UL (2019) Bruise damage susceptibility of pomegranates (Punica granatum, L.) and impact on fruit physiological response during short term storage Scientia Horticulturae 246:664-674

26. Ismail SM, Ali HM, Habiba RA (1993) GC-ECD and GC-MS analyses of profenofos residues and its biochemical effects in tomatoes and tomato products Journal of agricultural and food chemistry 41:610-615

27. Jacob K, Periago MJ, Böhm V, Berruezo GR (2008) Influence of lycopene and vitamin C from tomato juice on biomarkers of oxidative stress and inflammation British Journal of Nutrition 99:137-146

28. Joshipura KJ et al. (2001) The effect of fruit and vegetable intake on risk for coronary heart disease Annals of internal medicine 134:1106-1114

29. Kaewklin P, Siripatrawan U, Suwanagul A, Lee YS (2018) Active packaging from chitosan-titanium dioxide nanocomposite film for prolonging storage life of tomato fruit International journal of biological macromolecules 112:523-529

30. Khachik F, Carvalho L, Bernstein PS, Muir GJ, Zhao D-Y, Katz NB (2002) Chemistry, distribution, and metabolism of tomato carotenoids and their impact on human health Experimental biology and medicine 227:845-851

31. Konwar A, Kalita S, Kotoky J, Chowdhury D (2016) Chitosan-iron oxide coated graphene oxide nanocomposite hydrogel: a robust and soft antimicrobial biofilm ACS applied materials \& interfaces 8:20625-20634

32. Kumari P et al. (2017) SMART MATERIALS FOR SMART LIVING Development 95:135

33. Li W, Li L, Zhang H, Yuan M, Qin Y (2018) Evaluation of PLA nanocomposite films on physicochemical and microbiological properties of refrigerated cottage cheese Journal of Food Processing and Preservation 42:e13362

34. Maul F, Sargent S, Sims C, Baldwin E, Balaban M, Huber D (2000) Tomato flavor and aroma quality as affected by storage temperature Journal of Food Science 65:1228-1237 
35. Mohammad F, Arfin T, Al-Lohedan HA (2017) Sustained drug release and electrochemical performance of ethyl cellulose-magnesium hydrogen phosphate composite Materials Science and Engineering: C 71:735-743

36. Noshirvani N, Ghanbarzadeh B, Mokarram RR, Hashemi M (2017) Novel active packaging based on carboxymethyl cellulose-chitosan-ZnO NPs nanocomposite for increasing the shelf life of bread Food Packaging and Shelf Life 11:106-114

37. Ntagkas $\mathrm{N}$ et al. (2019) Light-induced vitamin c accumulation in tomato fruits is independent of carbohydrate availability Plants 8:86

38. Opara UL, Pathare PB (2014) Bruise damage measurement and analysis of fresh horticultural produce-a review Postharvest Biology and Technology 91:9-24

39. Ord J, Butler HJ, McAinsh MR, Martin FL (2016) Spectrochemical analysis of sycamore (Acer pseudoplatanus) leaves for environmental health monitoring Analyst 141:2896-2903

40. Patterson A (1939) The Scherrer formula for X-ray particle size determination Physical review 56:978

41. Pugazhendhi A, Kumar SS, Manikandan M, Saravanan M (2018) Photocatalytic properties and antimicrobial efficacy of Fe doped $\mathrm{CuO}$ nanoparticles against the pathogenic bacteria and fungi Microbial pathogenesis 122:84-89

42. Rodríguez A, Alquézar B, Peña L (2013) Fruit aromas in mature fleshy fruits as signals of readiness for predation and seed dispersal New Phytologist 197:36-48

43. Sablani S, Opara L, Al-Balushi K (2006) Influence of bruising and storage temperature on vitamin C content of tomato fruit Journal of Food Agriculture and Environment 4:54

44. ŞAHIN Ö (2020) Combined lodine, Iron and Zinc Biofortification of Tomato Fruit Iğdır Üniversitesi Fen Bilimleri Enstitüsü Dergisi 10:2242-2251

45. Sangeetha J, Philip J (2013) Synthesis, characterization and antimicrobial property of Fe 30 4-CysHNQ nanocomplex, with I-cysteine molecule as a linker RSC advances 3:8047-8057

46. Shandilya M, Thakur S, Thakur S (2020) Magnetic amendment in the fabrication of environment friendly and biodegradable iron oxide/ethyl cellulose nanocomposite membrane via electrospinning Cellulose 27:10007-10017

47. Shinde BA, Dholakia BB, Hussain K, Aharoni A, Giri AP, Kamble AC (2018) WRKY1 acts as a key component improving resistance against Alternaria solani in wild tomato, Solanum arcanum Peralta Plant biotechnology journal 16:1502-1513

48. Skolik P, McAinsh MR, Martin FL (2019a) ATR-FTIR spectroscopy non-destructively detects damageinduced sour rot infection in whole tomato fruit Planta 249:925-939

49. Skolik P, Morais CL, Martin FL, McAinsh MR (2019b) Determination of developmental and ripening stages of whole tomato fruit using portable infrared spectroscopy and Chemometrics BMC plant biology 19:1-15

50. Stan MS et al. (2016) Photocatalytic, antimicrobial and biocompatibility features of cotton knit coated with Fe-N-doped titanium dioxide nanoparticles Materials 9:789 
51. Stevens MA (1974) Varietal influence on nutritional value Nutritional Qualities of Fresh Fruits and Vegetables $\mathrm{p} L$ White, \& N Selvey, eds

52. Święch D, Paluszkiewicz C, Piergies N, Pięta E, Lelek-Borkowska U, Kwiatek W (2018) Identification of Corrosion Products on Fe and Cu Metals using Spectroscopic Methods Acta Physica Polonica A 133:286-288

53. Techane G, Yadav O, Yadav L (2019) Atomic absorption spectroscopic determination of some heavy metal contents in tomato (Lycopersicon esculentum Mill) fruit and water used for irrigation Net $\mathrm{J}$ Agric Sci 7:23-29

54. Thakur S, Kaur M, Lim WF, Lal M (2020a) Fabrication and characterization of electrospun ZnO nanofibers; antimicrobial assessment Materials Letters 264:127279

55. Thakur S, Rai R, Sharma S (2014) Study the antibacterial activity of copper nanoparticles synthesized using herbal plants leaf extracts Int J Bio-Technol Res 4:21-34

56. Thakur S, Shandilya M, Guleria G (2021) Appraisement of antimicrobial zinc oxide nanoparticles through Cannabis Jatropha curcasa Alovera and Tinosporacordifolia leaves by green synthesis process Journal of Environmental Chemical Engineering 9:104882

57. Thakur S, Shandilya M, Thakur S, Sharma DK (2020b) Growth mechanism and characterization of CuO nanostructure as a potent Antimicrobial agent Surfaces and Interfaces:100551

58. Thakur S, Shandilya M, Thakur S, Sharma DK (2020c) Growth mechanism and characterization of $\mathrm{CuO}$ nanostructure as a potent Antimicrobial agent Surfaces and Interfaces 20:100551

59. Thakur S, Sharma S, Thakur S, Rai R (2018a) Green synthesis of copper nano-particles using Asparagus adscendens roxb. Root and leaf extract and their antimicrobial activities International Journal of Current Microbiology and Applied Sciences 7:683-694

60. Thakur S, Thakur S, Kumar R (2018b) Bio-nanotechnology and its role in agriculture and food industry J Mol Genet Med 12:1747-0862.1000324

61. Venkatasubbu GD, Baskar R, Anusuya T, Seshan CA, Chelliah R (2016) Toxicity mechanism of titanium dioxide and zinc oxide nanoparticles against food pathogens Colloids and Surfaces $B$ : Biointerfaces 148:600-606

62. Verna G, Sila A, Liso M, Mastronardi M, Chieppa M, Cena H, Campiglia P (2021) Iron-Enriched Nutritional Supplements for the 2030 Pharmacy Shelves Nutrients 13:378

63. Watada AE, Tran T (1987) Vitamins C, BI9 and B2 contents of stored fruits and vegetables as determined by high performance liquid chromatography J Am Soc Hortic Sci 112:794-797

64. Willcox JK, Catignani GL, Lazarus S (2003) Tomatoes and cardiovascular health

\section{Tables}


Table.1 Antibacterial activity of synthesized CE@Fe $\mathrm{O}_{3}-\mathrm{NC}$ and Cellulose

\begin{tabular}{|c|c|c|c|c|c|}
\hline \multirow{3}{*}{$\begin{array}{l}\text { S. } \\
\text { No. }\end{array}$} & \multirow[t]{3}{*}{ Microorganisms } & \multicolumn{4}{|l|}{ Zone of inhibition in $\mathrm{mm}$} \\
\hline & & \multirow{2}{*}{$\begin{array}{l}\mathrm{a}-\mathrm{Fe}_{2} \mathrm{O}_{3} @ \mathrm{C}_{20} \mathrm{H}_{38} \mathrm{O}_{11} \mathrm{NC} \\
20 \mu \mathrm{g} / \mathrm{ml} \\
(\mathrm{HYF}-1)\end{array}$} & \multirow{2}{*}{$\begin{array}{l}\text { Cellulose } \\
20 \mu g / m l \\
\text { (HYF-2) }\end{array}$} & \multirow{2}{*}{$\begin{array}{l}20 \mu \mathrm{g} / \mathrm{ml} \text { of } \\
\text { Ampicillin } \\
\text { (Amp) }\end{array}$} & \multirow{2}{*}{$\begin{array}{l}\text { DMSO } \\
20 \mu \mathrm{g} / \mathrm{m}\end{array}$} \\
\hline & & & & & \\
\hline 1. & $\begin{array}{l}\text { Klebsiella } \\
\text { pneumoniae }\end{array}$ & $13 \mathrm{~mm}$ & 0 & $17 \mathrm{~mm}$ & 0 \\
\hline 2. & $\begin{array}{l}\text { Staphylococcus } \\
\text { aureus }\end{array}$ & $15 \mathrm{~mm}$ & 0 & $18 \mathrm{~mm}$ & 0 \\
\hline
\end{tabular}

Table.2 Means (average \pm s.d.) of Fe and Zn Elements Content of Tomato samples (mg/kg: dryweight basis)

\begin{tabular}{lll} 
Tomato samples & $\mathrm{Fe}(\mathrm{mg} / \mathrm{kg})$ & $\mathrm{Zn}(\mathrm{mg} / \mathrm{kg})$ \\
at $25^{\circ} \mathrm{C}$ & & \\
\hline UC1 & $21.8 \pm 0.24$ & $20.4 \pm 0.12$ \\
UC1A & $18.4 \pm 0.13$ & $24.7 \pm 0.10$ \\
\hline UC1B & $16.52 \pm 0.21$ & $22.4 \pm 0.19$ \\
\hline at $4{ }^{\circ} \mathrm{C}$ & & \\
\hline UC2 & $20.9 \pm 0.21$ & $21.4 \pm 0.41$ \\
\hline UC2A & $20.5 \pm 0.10$ & $22.4 \pm 0.13$ \\
\hline UC2B & $20.7 \pm 0.14$ & $22.5 \pm 0.20$
\end{tabular}

\section{Figures}




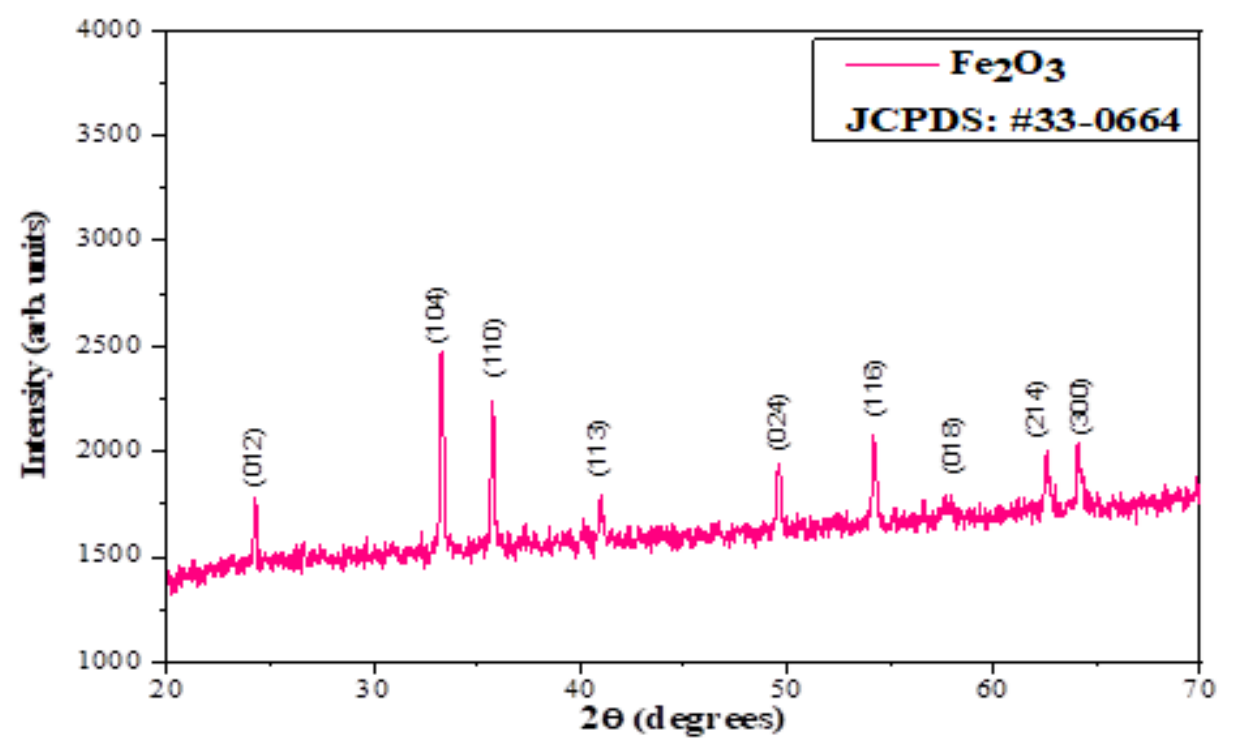

Figure 1

XRD analysis of Fe2O3 nanoparticles synthesized by Hydrothermal Method

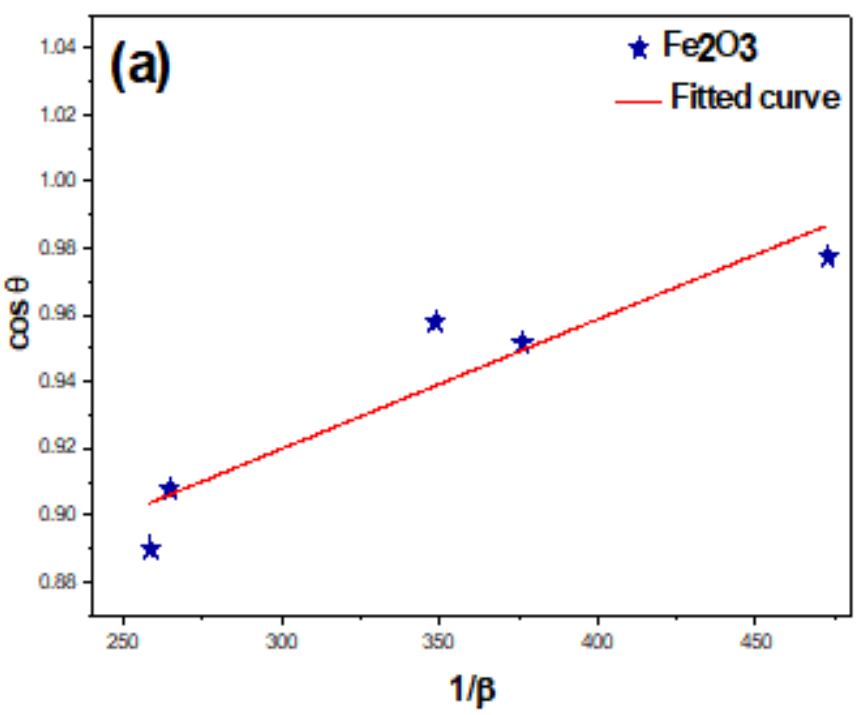

(a)

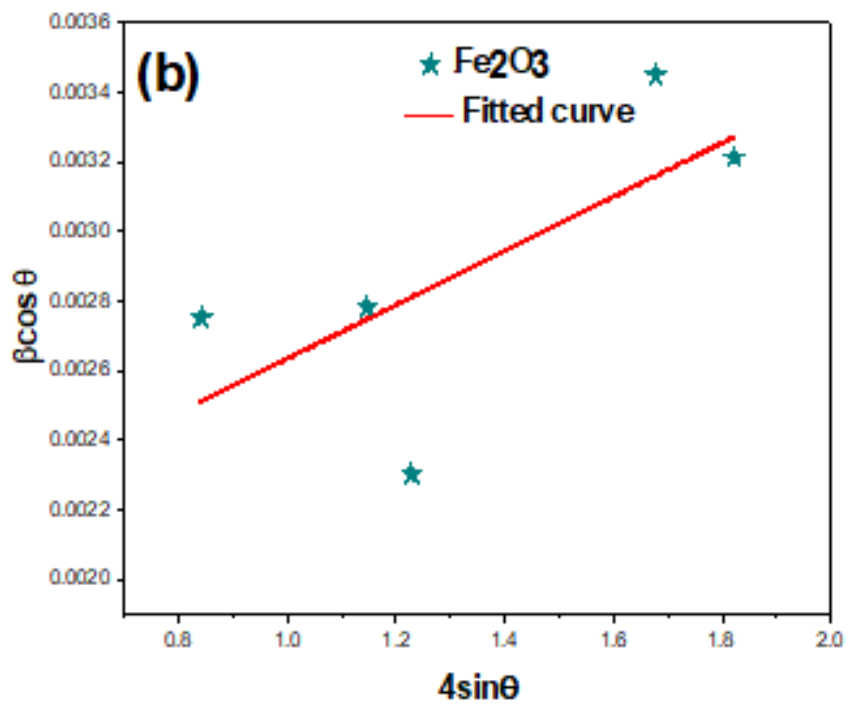

(b)

Figure 2

(a) Scherrer Plot of Fe2O3and (b) Williamson-Hall (W-H) Plot of Fe2O3nanoparticles 


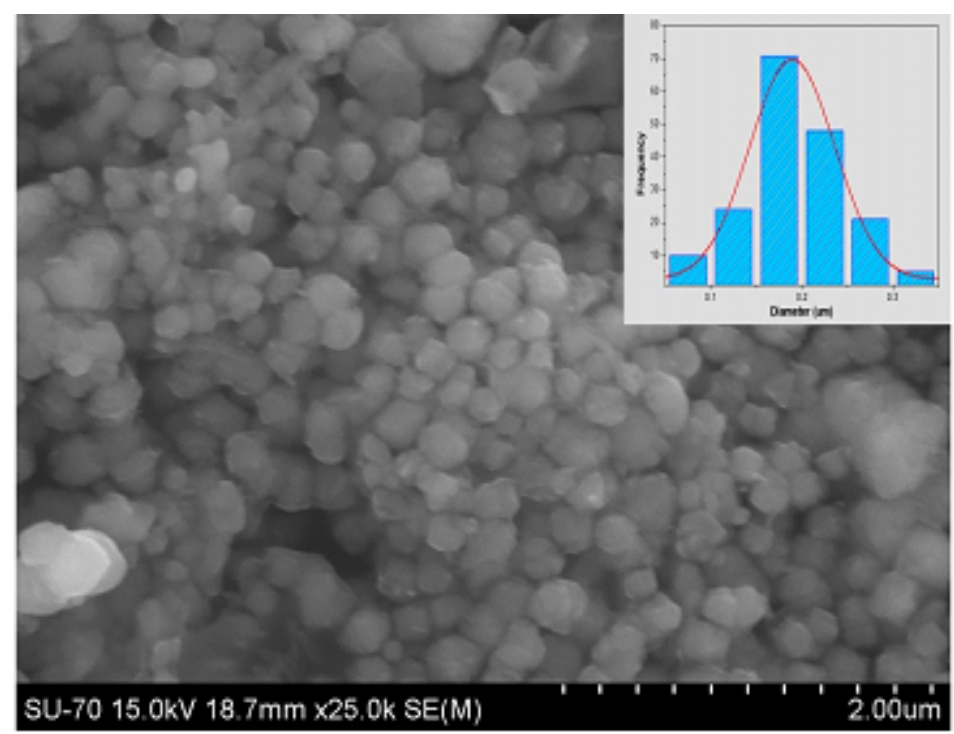

(a)

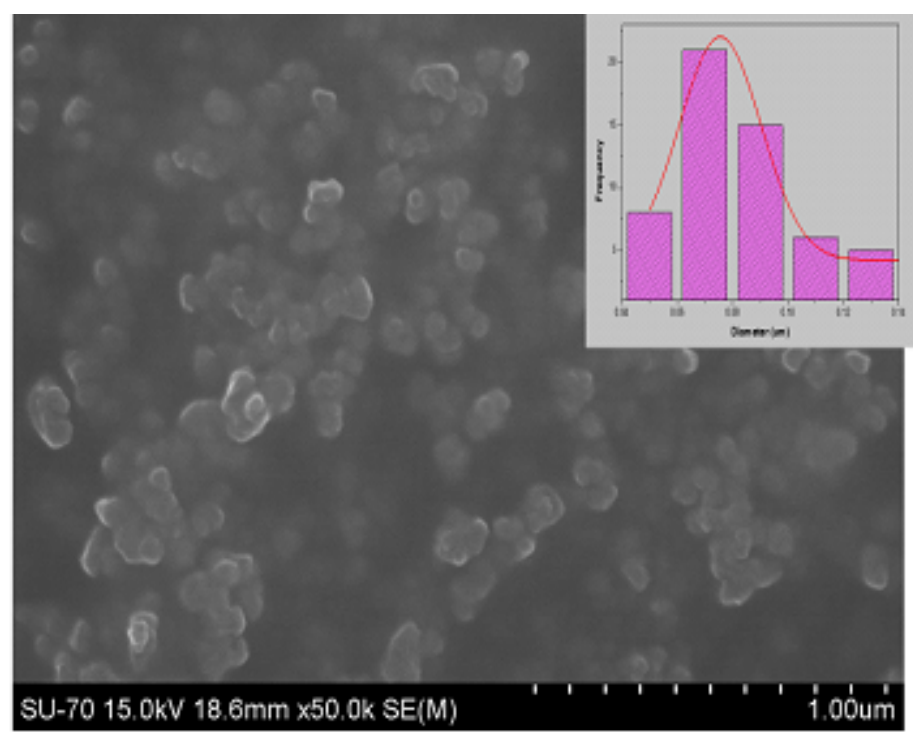

(b)

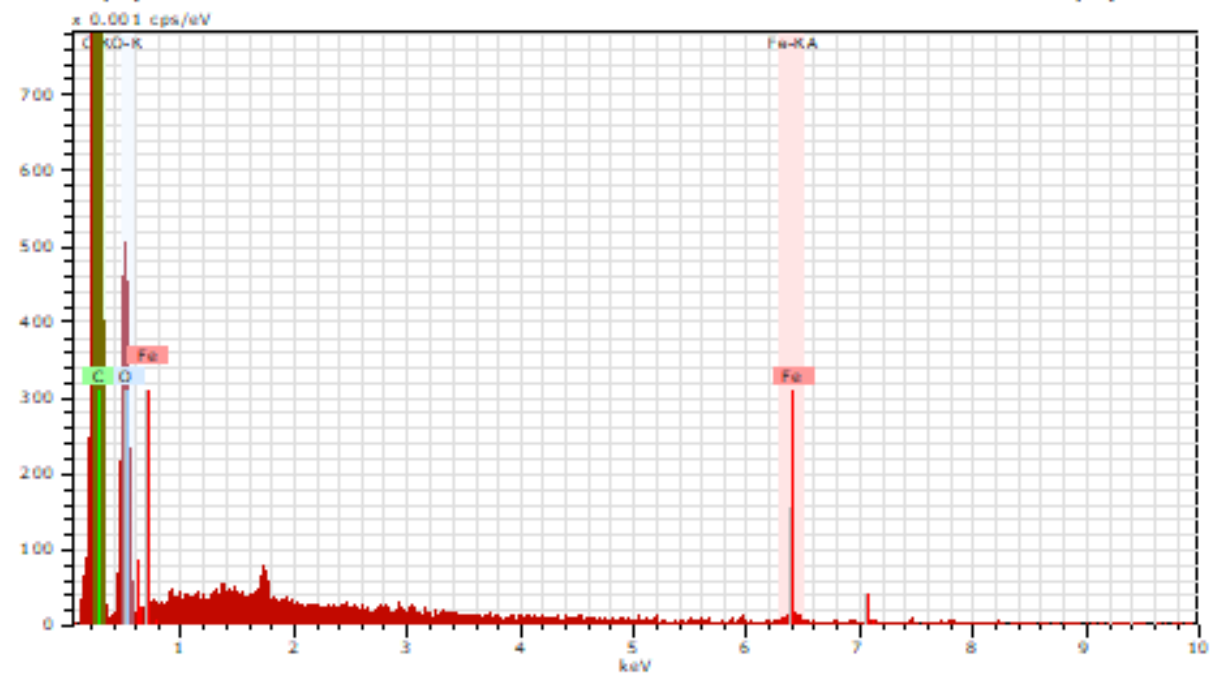

(c)

\section{Figure 3}

(a) SEM analysis of Fe2O3 nanoparticles (b) a-Fe203@C20H38011 NC (c) EDX-pattern of aFe2O3@C20H38011 NC 
$\mathrm{HYFl}-\mathrm{CE} @ \mathrm{Fe}_{2} \mathrm{O}_{3}-\mathrm{NC}$

HYF2-Cellulose

Amp- Positive control

DMSO-Negetive control

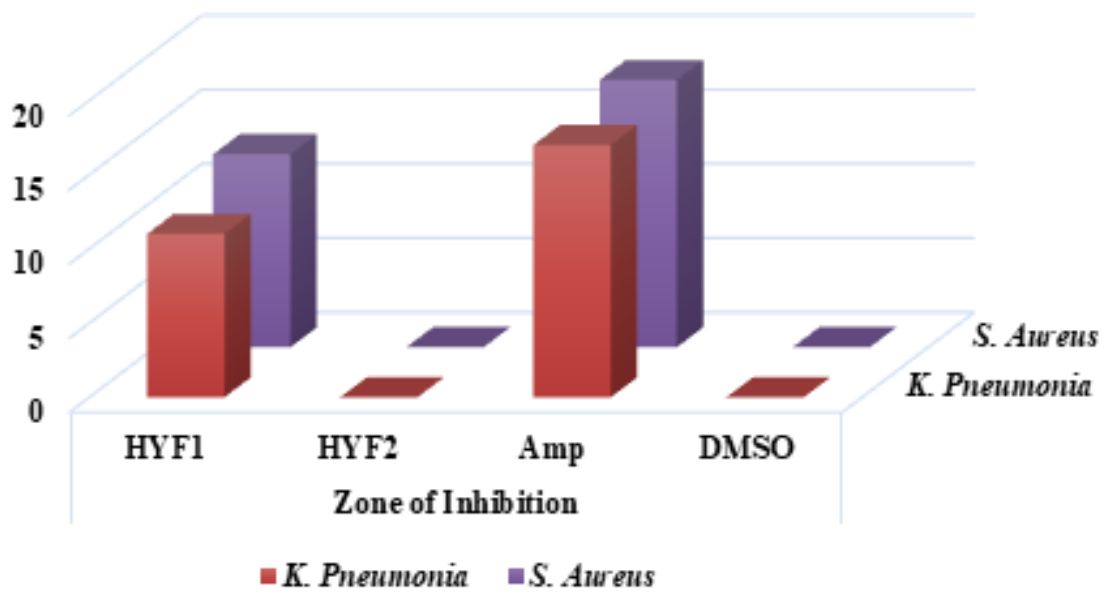

Figure 4

Inhibition Zone of synthesized a-Fe2O3@C20H38011 NC HYF-1, Cellulose HYF-2, Ampicillin and DMSO against Klebsiella pneumoniae and Staphylococcus aureus. 


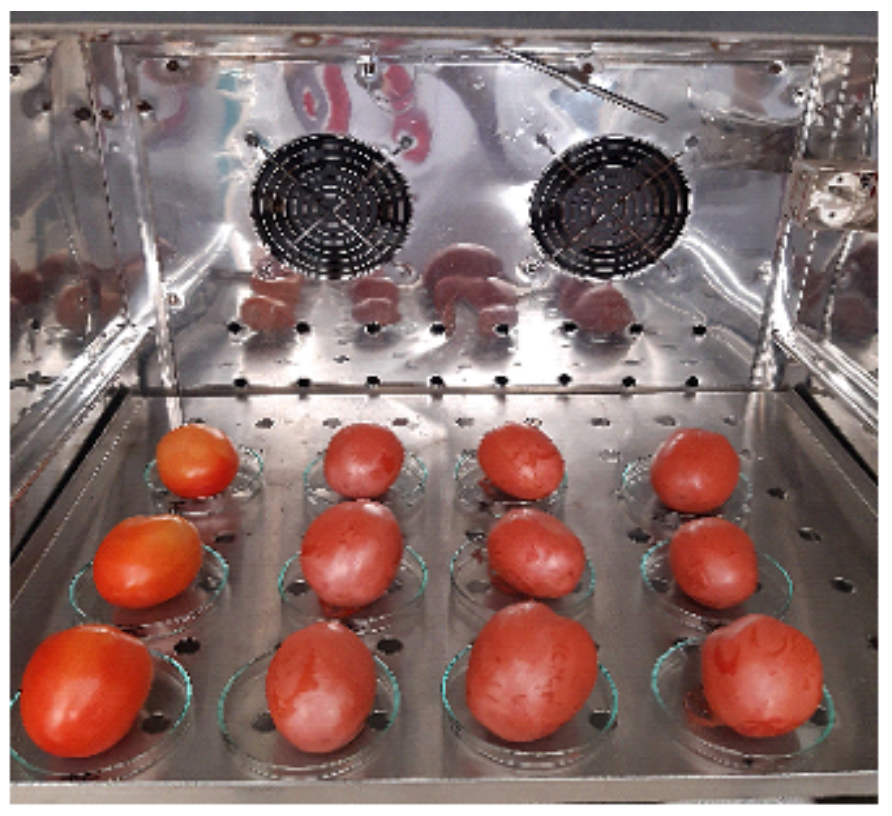

(a)

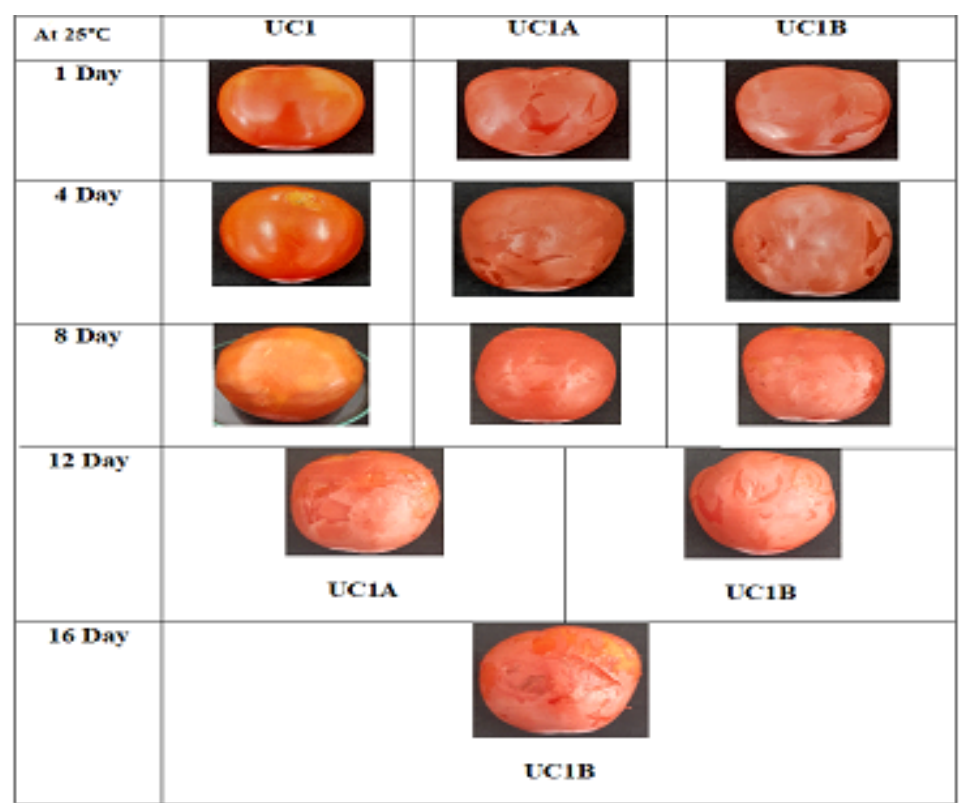

(b)

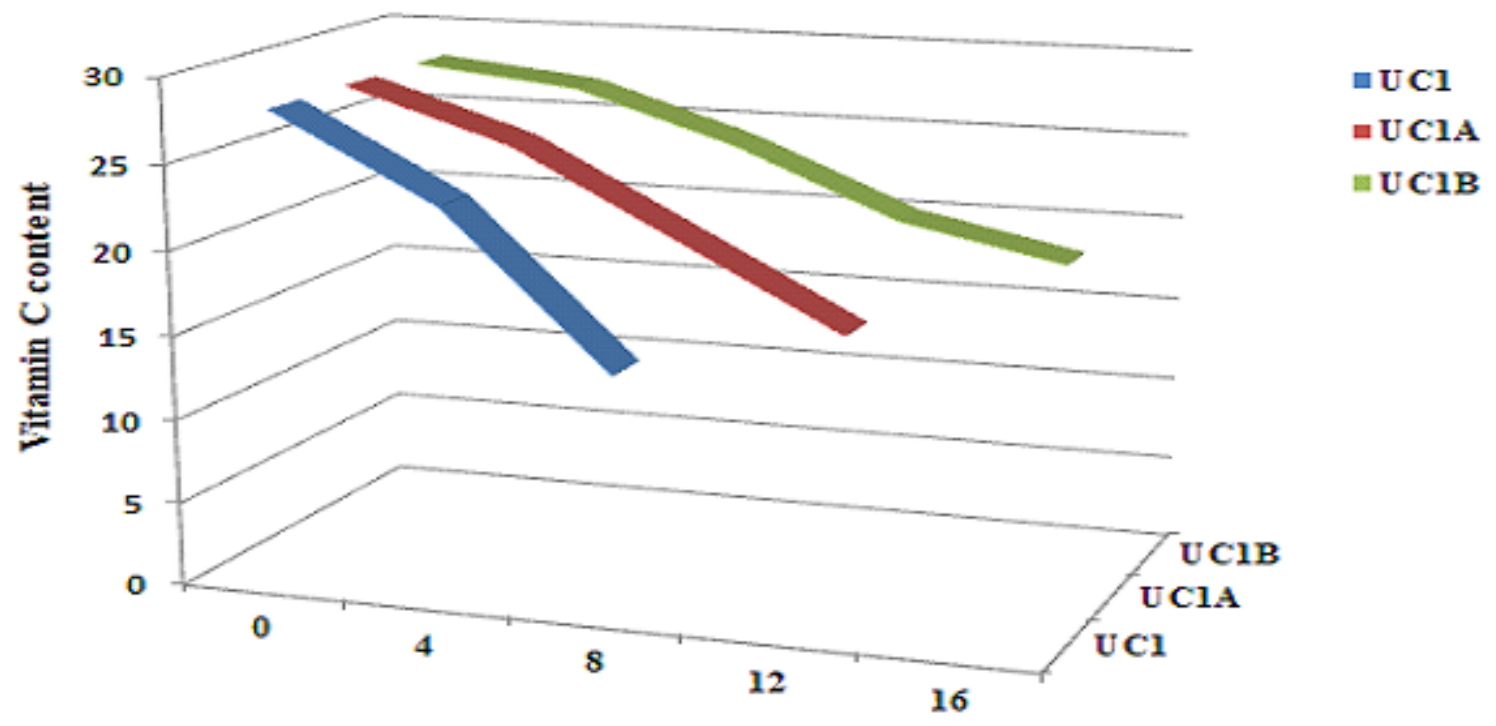

Storage Days $\left(25^{\circ} \mathrm{C}\right)$

(c)

Figure 5

(a) Tomatoes kept in storage study in the incubator at $25^{\circ} \mathrm{C}$ (b) Study of a-Fe2O3@C20H38011 NC nanocomposite coating at $25^{\circ} \mathrm{C}$ (c) Influence of a-Fe203@C20H38011 NC nanocomposite coating on vitamin $\mathrm{C}$ content in tomato during storage at $25^{\circ} \mathrm{C}$ on day $0-16$. 


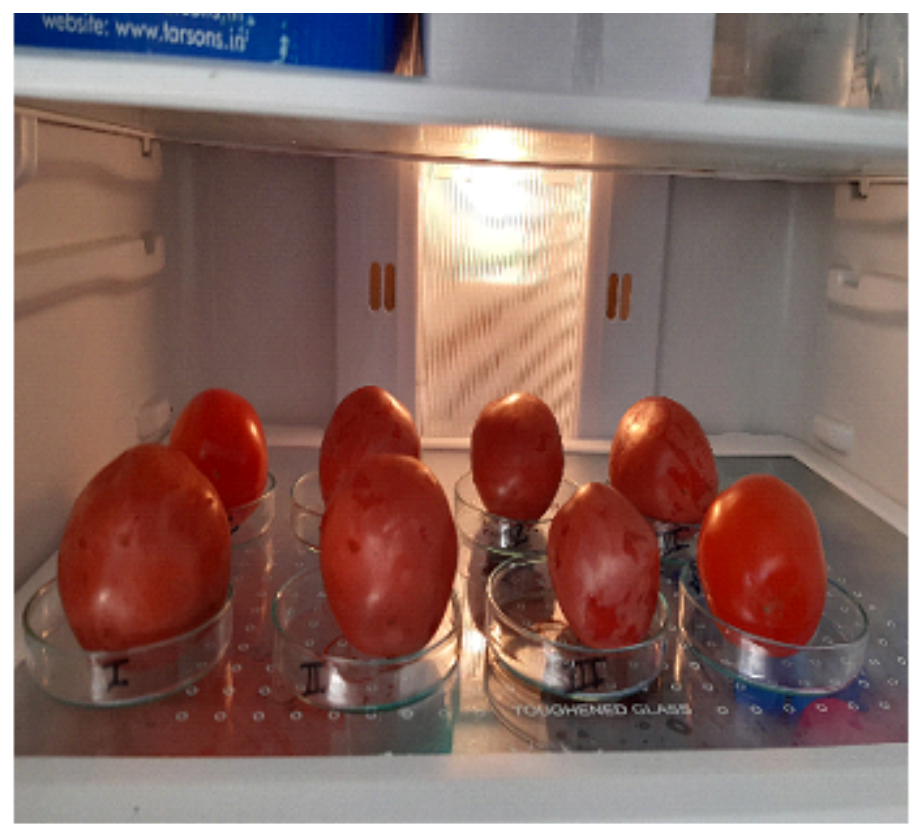

(a)

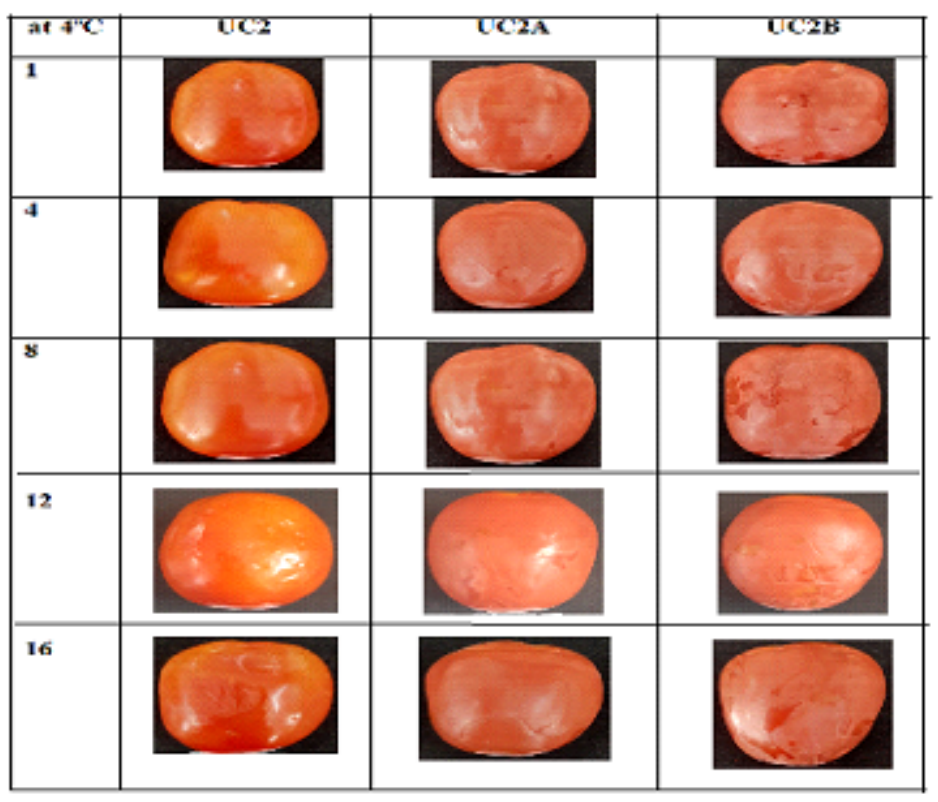

(b)

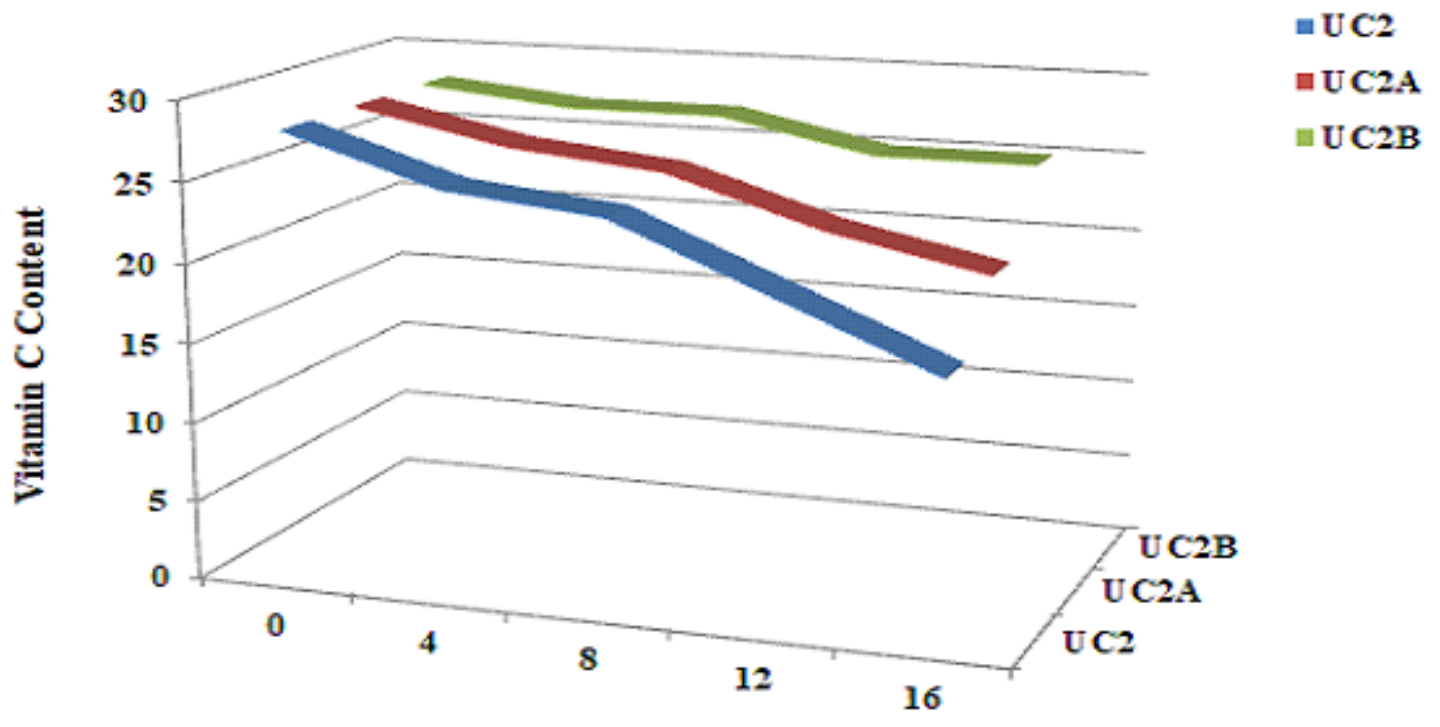

Storage Days $\left(4^{\circ} \mathrm{C}\right)$

(c)

Figure 6

(a) Tomatoes kept in storage study in the refrigerator at $4^{\circ} \mathrm{C}$ (b) Study of a-Fe2O3@C2OH38011 NC nanocomposite coating at $4^{\circ} \mathrm{C}$ (c) Influence of a-Fe2O3@C20H38011 NC nanocomposite coating on vitamin $\mathrm{C}$ content in tomato during storage at $4^{\circ} \mathrm{C}$ on day 0-16. 


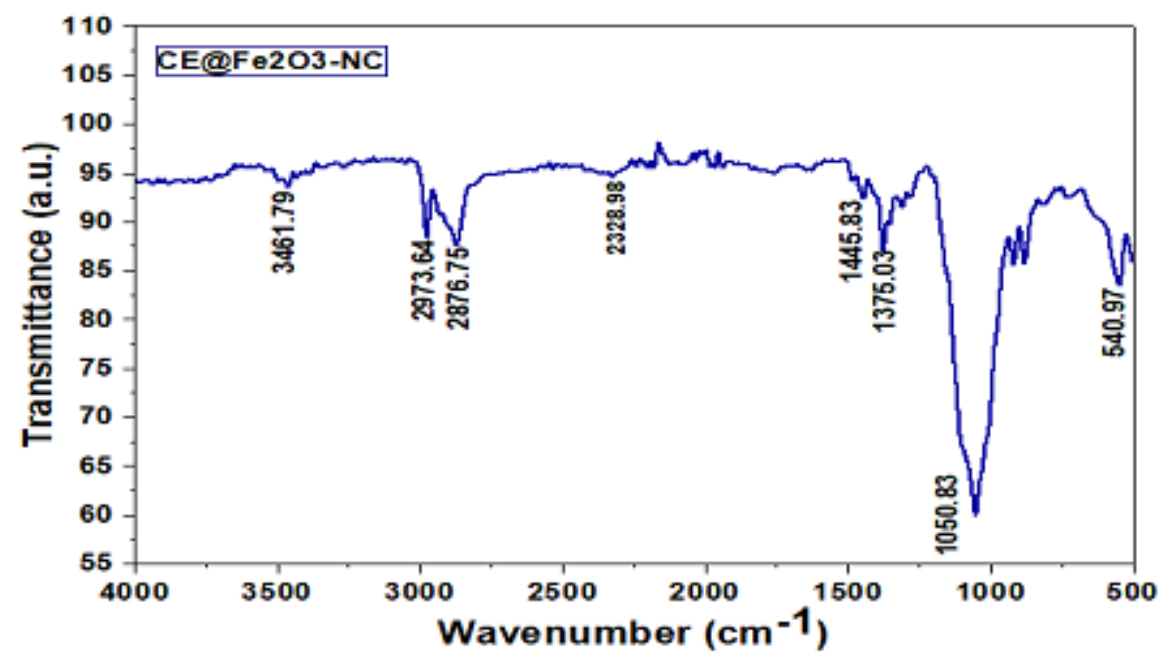

(a)

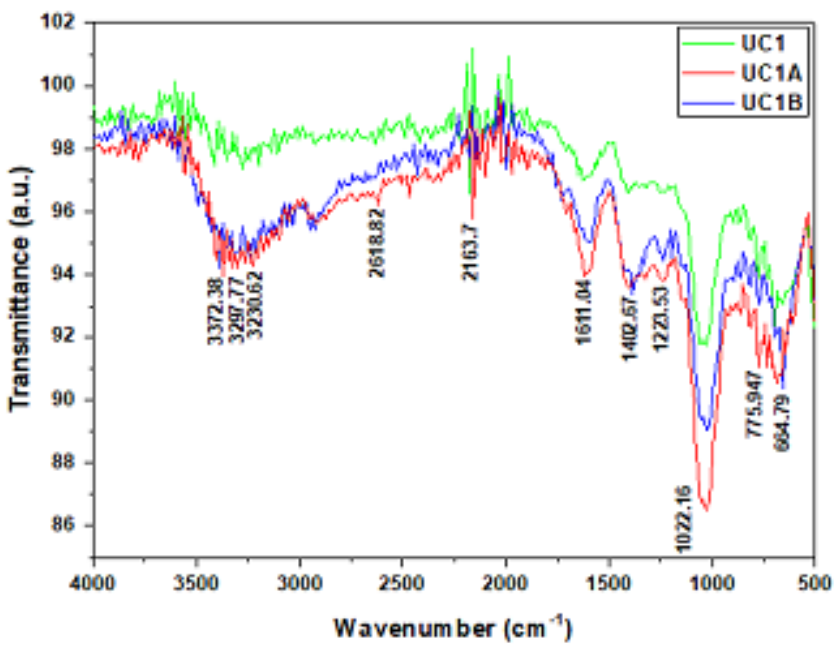

(b)

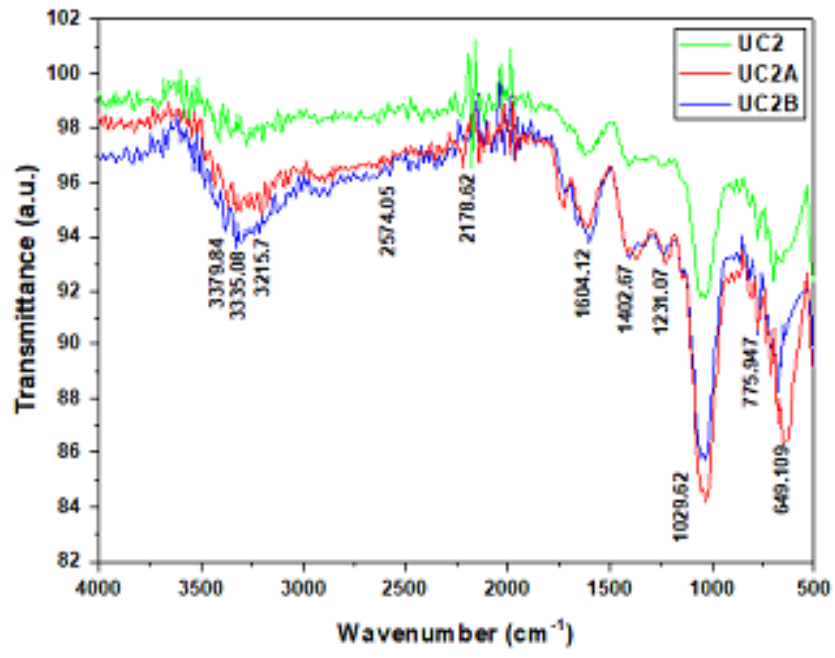

(c)

Figure 7

(a) FTIR spectra of a-Fe203@C20H38011 NC nanocomposite,(b) FTIR spectra of UC1, UC1A and UC1B samples under $25^{\circ} \mathrm{C}$ storage, (c) FTIR spectra of UC2, UC2A and UC2B samples under $4^{\circ} \mathrm{C}$ storage. 


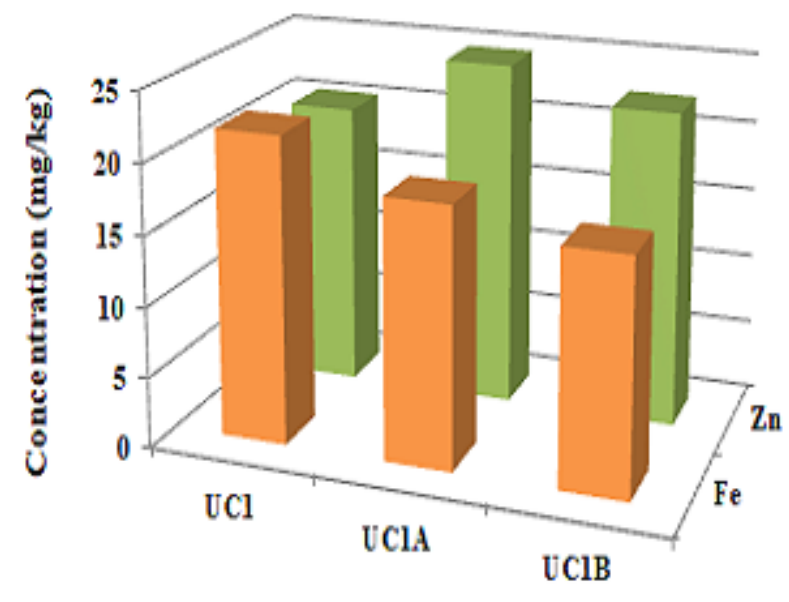

Tomato Samples $\left(25^{\circ} \mathrm{C}\right)$

(a)

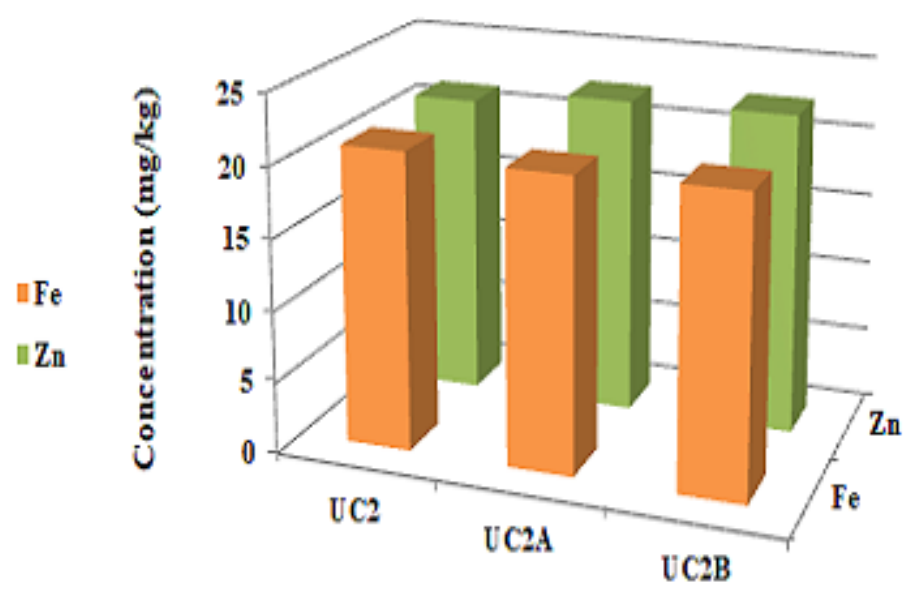

Tomato Samples $\left(4^{\circ} \mathrm{C}\right)$

(b)

Figure 8

(a) Fe and Zn Elements Content of UC1, UC1A and UC1B samples under $25^{\circ} \mathrm{C}$ storage, (b) Fe and Zn Elements Content of UC2, UC2A and UC2B samples under $4^{\circ} \mathrm{C}$ storage.

\section{Supplementary Files}

This is a list of supplementary files associated with this preprint. Click to download.

- GraficalAbstract.docx 